\title{
Gênero e sexualidades indígenas: alguns aspectos das transformações nas relações a partir dos Kaiowa no Mato Grosso do Sul
}

L Diógenes Cariaga

Universidade Federal de Santa Catarina, Florianópolis, Santa Catarina, Brasil

DOI 10.11606/issn.2316-9133.v24i24p441-464

resumo Neste artigo, busco trazer algumas consideraçôes sobre as transformaçóes pelas quais os Kaiowa e os Guarani têm passado no Mato Grosso do Sul, a partir de um enfoque nas relações geracionais e de gênero. Deste modo, trazer algumas consideraçóes a respeito do modo como as sexualidades - neste caso, homossexualidade - são vivenciadas pelos jovens kaiowa pode contribuir para reflexôes sobre como estes tematizam questôes acerca do modo de ser, das moralidades e das diferenças postas entre os pontos de vista geracionais. Assim, ao procurar trazer tais debates para a etnologia indígena, a expectativa é que esses aspectos da vida social possam contribuir para a descrição dos sentidos da inovação na socialidade ameríndia.

palavras-chave Etnologia indígena; Transformaçôes; Gênero; Geração; Kaiowa.

Gender and sexualities: a few aspects of the transformations in relations among the Kaiowa in Mato Grosso do Sul

abstract In this article I attempt to bring up some considerations on the transformations which the Kaiowa and the Guarani have undergone, in Mato Grosso do Sul, by focusing on relations of gender and generation. In this way, presenting some considerations regarding the way in which sexualities are experienced by Kaiowa youth - homosexuality, in this case - may contribute to reflections on how they frame questions about ways of life, moralities and the differences operated among generational points of view. Thus, by seeking to bring these debates into indigenous ethnology, it is expected that these aspects of social life might contribute to a description of the meanings of innovation in amerindian sociality.

keywords Indigenous ethnology; Transformations; Gender; Generation; Kaiowa. 


\section{Introdução}

A sexualidade e a orientação sexual dos indígenas são temas pouco explorados nas etnografias americanistas. Pesquisas como as de McCallum (2013) e Lea $(2010,1994)$ são referenciais no entendimento da articulação entre gênero - como categoria e como conceito - e outros aspectos da socialidade. Entretanto, o tema da orientaçáo sexual ou especificamente da homossexualidade permanece silenciado. ${ }^{2}$ Investigações como as realizadas por Fernandes $(2014 \mathrm{a}, 2014 \mathrm{~b})$ se conectam parcialmente aos interesses deste texto, de problematizar quais desafios estão mobilizados nessa temática no que tange as intersecçóes entre pesquisa sobre gênero e etnologia indígena. Pois, como já aponta McCallum (2013, p. 57) ao se referir ao trabalho de Fernandes (2013), a perspectiva comparativa do autor, aliada aos interesses em aproximar o conceito de terceiro gênero (two spirits) do movimento indígena queer norte-americano, esbarra na baixa interlocução com o corpus teórico sobre a corporalidade e socialidade ameríndia nas terras baixas da América do Sul. Como já adverte a autora (MCCALLUM, 2013), pesquisas dessa natureza são trabalhos ainda a ser realizados.

Avalio que o tema esbarra em questóes que entrelaçam limitaçóes e moralidades de como a etnologia indígena tem negligenciado interlocuções com pesquisas antropológicas sobre relaçóes de gênero e performatividade entre os gêneros, realizadas em sua maioria em "sociedades complexas", que teriam poucos efeitos para reflexóes sobre as transformaçóes ameríndias. Todavia, a partir de algumas experiências de campo junto aos Kaiowa e Guarani no Mato Grosso do Sul, pretendo demonstrar que dar mais atenção ao tema pode deslocar nossos pontos de vista sobre tais relaçôes entre os indígenas.

\section{Pesquisas sobre a sexualidade: negociando acordos tácitos}

Na pesquisa para o mestrado, meu interesse centrava-se nas transformaçóes do modo de ser entre os Kaiowa a partir da educação das crianças. Desse modo, a corporalidade e as categorias nativas sobre idade e ciclo de vida foram e são temas de interesse (CARIAGA, 2012). ${ }^{3}$ Inicialmente tive dificuldades em me aproximar do cotidiano de cuidado das crianças devido ao fato de eu ser homem, adulto, não kaiowa, solteiro e sem filhos, o que limitava minha presença à escola, mesmo já tendo proximidade com muitas famílias e lideranças na terra indígena onde realizei a pesquisa de campo. Despertava curiosidade nos professores e professoras o meu interesse, visto que este era um assunto de mães e pais. ${ }^{4} \mathrm{Na}$ concepção kaiowa, devido ao fato de não 
ter filhos e ser solteiro, eu era visto como mitäguasu - que pode ser entendido como menino grande (categoria que, aplicada a um adulto, não é nada positiva) -, pois, sem filhos, eu náo poderia ser classificado como homem adulto (ava), mas, por ser não kaiowa e ser "professor", recebia o tratamento de karai kuimba'e- (aquele homem branco jovem).

Para as formas de conduta e moralidade kaiowa, ${ }^{5}$ a condição de um homem adulto, solteiro e sem filhos o torna frágil, devido a sua impossibilidade de produzir relaçóes de parentesco, o que dificulta que se assuma posiçôes de prestígio político. Entre os Kaiowa, produzir pessoas é o principal meio para alcançar e disputar posiçóes de prestígio, pois a condiçáo do ego é sempre mediadora entre diferentes modos de ser, marcados por posiçóes geracionais no interior da parentela. O parentesco kaiowa foi descrito como uma ampla rede de relaçóes que conjugam modalidades de consanguinidade, descendência, afinidade fortemente marcados pela residência e comensalidade, que produzem formas amplas de relacionalidade. ${ }^{6}$ Autores como Pereira $(1999,2004 a)$ e Benites (2009) dáo ênfase à importância de se entender a noção de pessoa kaiowa como emergente das relaçóes produzidas entre as categorias mais amplas da socialidade - ñande reko $-{ }^{7}$ passando por formas nativas de enunciar as diferenças nos modos de significação do mundo entre os Kaiowa e outros humanos e não humanos - ore reko. ${ }^{8}$

A posição de homem adulto solteiro e sem vínculos com nenhum fogo familiar pode colocar em vulnerabilidade o status e o prestígio do homem entre os Kaiowa, o que o impossibilita, por exemplo, de assumir a conduçáo de uma parentela e de aprendizagem do teko marangatu (modo como os Kaiowa conceituam seu xamanismo). Essas características também colocam em risco a possibilidade de se assumir algumas posiçôes de liderança e chefia, como nos acampamentos de retomada dos territórios tradicionais reivindicados pelas famílias kaiowa e guarani. Esse conjunto de atributos, no sistema classificatório do parentesco e da pessoa kaiowa, confere ou potencializa as acusaçóes de práticas de feitiçaria - pajé vaí, que é o avesso dos ñembo'e (canto/reza/oração de potência curativa/restaurativa feita pelos ñanderu/rezador - xamã). ${ }^{9}$ Desse modo, o homem adulto, solteiro e sem filhos pode ser potencialmente identificado como feiticeiro ou falso xamá (ñanderu guảu ), principal agente da desordem e da desarticulação do teko porä (modo correto de ser e viver).

Assim, a minha condição de homem solteiro dava aos índios abertura para questionarem minha vida pessoal e familiar, alvo de especulaçóes dos Kaiowa, especialmente pela percepção, por parte deles, de que os brancos demoram a ter filhos. Parte dos questionamentos resumia-se ao porquê de termos filhos táo tarde, e terminava por abrir espaços para brincadeiras jocosas sobre a minha sexualidade. 
Entre os interlocutores, nunca houve uma pergunta direta sobre a minha orientação sexual, o que não os impedia de especular sobre ela. Desse modo, uma primeira observação sobre o que a homossexualidade afeta entre os Kaiowa é o status de "homem - ava". O termo ava é a categoria que expressa o entendimento acerca da humanidade; pode ser traduzido por gente, pessoa, humano, mas, ao utilizarem como gênero gramatical masculino, torna-se sinônimo de homem adulto. Na perspectiva de ava enquanto gente, pessoa, as relaçóes matrimoniais são vistas como formas política de produção de prestígio e afetam o modo como as pessoas são qualificadas em relação a casamentos que podem frutificar em termos de status. Tanto para os homens quanto para as mulheres, a condição que ser marido-e-pai e esposa-e-mãe confere às pessoas, entre os Kaiowa - e, como descreveu Cavalheiro (2015) sobre os Mbyá no Rio Grande do Sul, a importância política conferida através da conjugalidade e da produção da parentela entre os coletivos falantes de língua guarani - expressam formas de ação política que não equivalem às relações entre os gêneros como o feminino reduzido ao doméstico/privado/natureza e o masculino ao social/ público/cultural.

Assim como a autora, penso que a categoria correspondente à natureza entre os Kaiowa não se restringe a questôes ecológicas; ao contrário, é uma paisagem densamente povoada por entes que lhe conferem uma economia política das relaçóes, como sugere Pereira (2004a) para os Kaiowa. Em síntese, ambos os autores apontam uma visão purificada que cinde natureza e cultura, como proposto por Latour (1995), que náo se aplica aos modos de existência entre os coletivos falantes de guarani, já que a noção de subordinação da natureza à cultura não se sustenta, assim como o das mulheres aos homens.

Como apontaram Seraguza (2013) e Pereira (2004a) em suas etnografias da socialidade kaiowa, é possível verificar a existência de fogos familiares liderados apenas por mulheres em que a condição de chefia, tanto para homens, quanto para mulheres, prescinde da conjugalidade. De certo modo, para os homens kaiowa, continuar solteiro e sem filhos é um modo de renunciar ao prestígio e abrir margens para dúvidas acerca desse estado.

A sexualidade, de modo geral, náo se tornou um assunto prioritário devido ao pouco interesse na época e à dificuldade de tornar uma conversa fluida na interlocução com homens e mulheres kaiowa. Inicialmente, as razóes que guiaram a minha atenção à homossexualidade entre os indígenas foram motivadas pelo interesse de um jornalista, editor de uma revista voltada para o público gay, que me convidou a participar de uma edição temática sobre "Diversidade na Diversidade", contribuindo com algumas entrevistas. $\mathrm{O}$ objetivo era compor uma reportagem que explorasse a homossexualidade nas diferentes "culturas". 
Ao ser questionado se havia, entre os Kaiowa, homens gays, afirmei que sim, mas que não tinha informações sobre o modo como ser homossexual era vivenciado, porque eu não conhecia "nenhum kaiowa gay assumido". Assim, ele me sugeriu que eu realizasse algumas entrevistas com os "não assumidos”. Então, ao voltar para o Mato Grosso do Sul, procurei meios e estratégias para romper "um certo acordo tácito" que existia com os possíveis interlocutores, visto que frequentávamos ambientes comuns, como locais de trabalho e "lugares gays" em Dourados, segunda maior cidade do estado, onde vivem cerca de 15 mil indígenas kaiowa, guarani e terena - a maior parte residente no interior da Reserva Indígena de Dourados, dividida entre as aldeias Jaguapiru e Bororo. ${ }^{10}$

Defino como acordo tácito a condição de que a minha homossexualidade e a dos potenciais entrevistados não eram um assunto que nos aproximasse, mesmo já tendo nos encontrado constantemente em um bar gay da cidade. Eu havia mapeado três jovens kaiowa para que pudesse entrevistá-los para a matéria, e elaborei algumas estratégias para abordá-los, visto que me aproximar para questioná-los sobre as suas sexualidades passava por negociar, nas entrevistas, a partir da ruptura do silenciamento com que as nossas homossexualidades poderiam ser tratadas no cenário das nossas relaçóes em campo: assumir a minha homossexualidade diante dos meus interlocutores e expor a homossexualidade deles colocava em jogo questóes que não eram costumeiramente tratadas no âmbito das pesquisas acadêmicas, pois os três já haviam colaborado em muitas dessas. Assim, avançamos para um ciclo de entrevistas individuais sobre a trajetória de vida, experiências sexuais e como refletiam sobre ser índio e gay.

Essas conversas foram realizadas em 2013 com dois jovens que se mostravam dispostos a falar sobre o assunto com maior franqueza. Algumas ocorreram de forma individual e outras em dupla. É a partir desse material, dos diálogos com eles sobre si próprios e sobre como percebiam as suas homossexualidades no cotidiano nas aldeias, que procuro trazer algumas reflexões produzidas durante nossas conversas. Em comum, ambos não residem na Reserva Indígena de Dourados, possuem formação de nível superior e atuam na área dos serviços de saúde indígena oferecidos pela Secretaria Especial de Saúde Indígena no atendimento nas aldeias. Desse modo, as questóes discutidas e as reflexóes dos Kaiowa emergem em um contexto de vida em que os saberes, técnicas, discursos e moralidades do modo de ser dos brancos - karai reko - são agências mediadas cotidianamente pelas posiçóes (índios jovens, "gays", morando fora da aldeia) que os interlocutores ocupam e pelas redes em que circulam, entre a vida com os parentes na aldeia, nos serviços públicos e com a cidade de Dourados. ${ }^{11}$ 


\section{Moralidades e relações jocosas: prestígio, parentesco e relações entre jovens e velhos.}

Para os jovens interlocutores, que se identificam como gays, a opção em morar fora da RID passa por uma escolha consciente de evitar tensóes e desgastes devido às especulaçóes sobre a sexualidade dos jovens, pois nos modos de classificaçáo de conduta da pessoa - ava reko - é comprometedor que homens com cerca de trinta anos náo tenham seu próprio fogo familiar. Sobre esse aspecto, trago trechos da conversa com um dos jovens que atuava no Polo Base da Sesai:

Desde pequeno eu sabia que tinha diferença entre eu e os meus irmãos. Eu nasci em Amambai (na aldeia) e lá, na época, tinha bem menos gente morando que hoje em dia, mas como eu queria estudar e lá não tinha condiçóes vim morar com minha tia aqui em Dourados [...]. Daí, quando mudei para cá, fui estudar na Missão [Missão Evangélica Caiuá, mantida pela Igreja Presbiteriana]... Na missão um dia os meninos mais velhos fizeram coisa comigo... mesmo pequeno, eu tinha gostado... hoje eu entendo melhor o que se passava, mas na época foi muito ruim, porque todo mundo ficou sabendo, daí o marido da minha tia me pôs na igreja, pra ver se eu mudava. [...] Eu quis, porque eu pensava na época que era errado, porque não sabia de ninguém indígena que nem eu. Namorei mulher, mas sabia que não era isso, mas era difícil porque não podia ter nada com outro índio, porque imaginava que não tinha. [...] Daí, quando fui fazer faculdade, vi que na cidade tinha bastante, mas achei que era da cultura dos brancos... que é diferente, né? Daí, aprendi também no curso que havia orientaçóes sexuais diferentes entre homem e mulher. Mas no nosso sistema não é assim.

A ideia de que a homossexualidade é um "traço cultural" dos brancos, que não pode ser vista como uma prática sexual comum entre os Kaiowa, permeia parte das reflexóes e é também produzida a partir da adesão a igrejas evangélicas e neopentecostais, que têm muitos fiéis e produzem ascendência política sobre os moradores da RID, visto que há muitas famílias que seguem as doutrinas religiosas que tratam o assunto como pecado ou desvio de conduta. Desse modo, as narrativas evocam em grande parte um discurso religioso sobre o pecado, o desvio e sobre as funçóes reprodutivas do corpo masculino e feminino. Essa questão foi um tópico comum nas conversas com um dos interlocutores que salientava: 
Tanto para os brancos como para os Guarani isso não é certo. Eu acho que é uma coisa nova, do nosso tempo. Por isso ninguém entende direito. Tudo que é novo causa estranheza, né? Porque na nossa cultura tem o papel que é do homem e que é da mulher. Porque para a gente não tem como ter família se não for assim. Porque cada um tem sua importância para cuidar dos filhos.

Durante as conversas era difícil avançar sobre tópicos como homoerotismo e as experiências sexuais vivenciadas, situaçóes em que eu me sentia mais interlocutor do que pesquisador, porque a partir das minhas experiências se desenvolviam os assuntos. Semelhante ao que relata Arisi (2012), o interesse em saber das minhas atividades sexuais era o que garantia a produção de relatos e nos punha em uma posição simétrica em relação aos interesses mútuos sobre práticas, modos e formas de fazer sexo.

Contudo, eles tinham muita resistência a falar de sua vida sexual por avaliarem que a homossexualidade é um aspecto da cultura dos brancos, o que me levava a questioná-los em que medida era uma prática exclusiva dos brancos, se eles tinham me relatado relacionamentos afetivos e sexuais esporádicos com outros indígenas. Faço essa diferenciação em razão de que, em uma conversa em dupla com jovens, em que ambos fizeram comentários de que já tinham se envolvido por mais tempo com outros indígenas, eles descreveram estas experiências como namoro, devido ao maior tempo de duração do relacionamento. Porém, as formas mais comuns eram as práticas sexuais rápidas e quase anônimas durante a adolescência na aldeia.

Os comentários que se seguiram davam a entender que o sexo com outros indígenas aconteceu somente no início da puberdade, a partir de experiências de descoberta das zonas erógenas do corpo, com a masturbação entre pequenos grupos de meninos da mesma faixa etária. Porém, essas experimentaçóes foram muito curtas e pontuais, porque, se continuassem a ter práticas identificadas como sexuais com outros meninos, iam ficar conhecidos como kuimba'e revikuera - "jovem que tem jeito que usa o ânus". A palavra tevi, que é como traduzem gay, é muito próxima da de revi, que é a tradução para ânus. Inclusive, ouvi os homens kaiowa heterossexuais, nas rodas de conversa, empregarem revi e tevi de forma ambígua, em termos jocosos, para pôr em duvida a heterossexualidade dos presentes.

Quando perguntei a respeito, se em algumas ocasióes teriam se sentido discriminados entre seus parentes ou na aldeia, parte das reflexóes apontava que a decisão de morar fora da aldeia é uma estratégia para fugir desse assédio. Mas o que avaliavam como mais difícil era que algumas outras escolhas anteriores, como fazer faculdade e morar fora da aldeia, assim 
como não se casar, implicavam em um bom distanciamento das relaçóes e das implicaçôes em viver na aldeia entre e com parentes. Os Kaiowa costumeiramente gostam de enfatizar a importância de viver entre seus parentes. Mas no contexto de adensamento populacional vivido na RID, agravado pelo processo histórico de contingenciamento territorial, essa forma prescritível da vida social kaiowa se torna problemática, pois as residências são extremamente próximas umas das outras, fator que aumenta as tensóes provocadas pelo excesso de vizinhança, como as fofocas.

A exemplo do que descreve Vanzolini (2010) sobre os Aweti do Alto Xingu, a vida íntima alimenta substancialmente as fofocas, e estas, por sua vez, produzem em ambos os contextos - kaiowa e xinguano - intensas formas de trocas de acusaçóes, que provocam movimentos, pois sempre se referem aos outros. Nesse sentido, a fofoca entre os moradores da RID impulsiona açóes e movimentos políticos entre as famílias extensas, como trocas de lideranças, mudanças nos cargos políticos nas agências governamentais, transferência de domicílio, acusaçôes de feitiçaria, que costumeiramente pairam sobre os homens solteiros e desconectados de fogos domésticos.

Por conseguinte, morar fora da aldeia é um meio de manter uma boa distância dessas situações, produzindo, nas reflexões dos jovens interlocutores, as possibilidades para mediarem os atritos eventuais diante das moralidades kaiowa. Optar por morar na cidade não implica um rompimento de conexóes familiares, políticas e morais, mas é um meio de mediar as tensóes inerentes a situaçóes em que a homossexualidade pode circular como fofoca. Desse modo, faz-se necessário refletir sobre essas práticas e situaçóes - em que se manter distante das fofocas é o meio ideal para uma boa convivência - com o intuito de abrandar os modos como as parentelas kaiowa diferenciam-se entre si. Benites (2009), ao descrever os aspectos mais minimalistas da vida social kaiowa, identifica que cada parentela possui modos de se diferenciar, o que ele chama de modos de ser e estilos comportamentais (teko laja). Na etnografia do antropólogo kaiowa (BENITES, 2009, p. 20), teko laja é um dos modos de composição do teko retã: modo de ser múltiplo de conjuntos dessas familias indigenas kaiowá. $O$ teko retã continua sendo, no entanto, um ñande reko, um "nosso modo de ser", sempre contraposto ao karai kuera, modo de ser do náo indio.

Neste sentido, mais do que explorar os regimes ontológicos sobre as diferenças entre o ñande reko e o karai reko, procuro aproximar ao rendimento de teko laja um campo conceitual das moralidades kaiowa, de modo análogo às formulaçóes de Sztutman (2009, p. 229) sobre a "moral imanente própria aos povos ameríndios, a uma ética do decoro e moderação", contida em sua análise sobre um conjunto de narrativas míticas ameríndias 
nas obras de Lévi-Strauss, em especial sobre a "História de Lince" (1993), no terceiro do volume das Mitológicas, $A$ origem dos modos à mesa (LÉVI-STRAUSS, 2006). Ao produzir analogias entre a transformação-produção de alimentos e, por sua vez, de pessoas, Sztutman (2009, p. 301-302, grifos do autor) argumenta conceitualmente que a importância da boa distância expressa nas inversóes de valores dos pares duais descritos por Lévi-Strauss é o lugar da boa relação. No contexto dos meus interlocutores, para manterem boas relaçóes com suas famílias, moradoras da Reserva Indígena de Dourados, a estratégia é se manter distante das fofocas que permeiam o cotidiano das pessoas, para que a homossexualidade deles não seja apontada como componente prejudicial aos teko laja de suas parentelas.

Nesse sentido, este texto se limita a trazer fragmentos de narrativas kaiowa para compor esse painel e náo tem o intuito de transcrever uma longa narrativa mítica e cosmológica, até mesmo porque esta não era a linguagem utilizada pelos jovens kaiowa durante nossas conversas e entrevistas. Contudo, o que pretendo extrair desse enunciado é a imagem acerca da produção do teko, que associa uma ampla rede de relaçóes entre humanos e náo humanos que povoam a cosmologia, mitologia e cosmografia do coletivo. Relaçóes que conectam os conhecimentos e socialidades produzidas no tempo mítico da criação do mundo kaiowa (teko ymaguare, tempo em que homens, animais e seres celestes se comunicavam) com os modos como exprimem "ser" e "conhecer" nos dias atuais (teko koa'nga), o que produz sentidos para descrever a continuidade da vida social e dos conhecimentos (teko pyahu) através da produção e educação da pessoa kaiowa (teko mbarete).

Seguindo nessa mesma direçáo, Teixeira-Pinto (2009) sugere que o tema da "boa distância", em Lévi-Strauss (2006), nos indica que a moralidade ameríndia, emerge da própria reflexão moral indígena. A opção de Teixeira-Pinto (2009, p. 197) por aspear a palavra moral orienta o leitor a não justapor a moralidade imanente dos mitos à "nossa moral". A análise pretende conduzir uma leitura na qual a moralidade nos mitos é imanente, porque ela não é descritiva, não se limita a definiçóes classificatórias ou apriorísticas.

Desse modo, as questóes relativas à moralidade ameríndia, como sugerem Sztutman (2009) e Teixeira-Pinto (2009), estão situadas de forma a extrair da mitologia o que há de "moral" nas relaçóes entre aparentes conjuntos opositores. A moralidade ameríndia extraída das formas expressivas indígenas não está presa a fatos, objetos, linguagens, e as operações de sentidos que os mitos realizam estáo em um nível mais elevado, "sua substância não se encontra nem no estilo, nem no modo de narração, nem na sintaxe, mas na história que nele é contada" (LÉVI-STRAUSS, 2008, p. 299, grifo do autor). 
Essa perspectiva parece ser promissora para refletirmos em como se operam as formulações da "filosofia moral ameríndia", para que possamos realizar, em conjunto com os interlocutores, questionamentos a respeito dos sentidos e modos de problematizaçáo das transformaçóes em suas relações políticas, cosmológicas e míticas. Pois entendo que, ao trazer o tema da sexualidade a partir de um diálogo com questóes articuladas a reflexóes sobre gênero e geração, a filosofia moral ameríndia assegura que não se tome a sexualidade apenas enquanto tema que interessa aos antropólogos e antropólogas, mas como como um campo amplo das relaçóes no cotidiano indígena.

Procuro chamar atenção a isso de modo mais assertivo devido ao próprio itinerário da abordagem dos interlocutores, reconhecendo que havia um interesse pontual no tema, que a princípio não dialogava com meu objeto de pesquisa em andamento no doutorado. ${ }^{12}$ Entretanto, ao realizar as entrevistas e articulá-las às experiências de campo, para, a partir disso, produzir um texto etnográfico, me deparei com o tema da moralidade ameríndia como nexo que conecta redes de relaçóes presentes no contexto de vida atual dos Kaiowa.

Em vista disso, pensar a moralidade kaiowa como diferentes modos de pensar e estar no mundo, a partir dos efeitos da intensificação das relaçóes com os brancos, pode atuar enquanto uma tecnologia capaz de mediar as transformaçóes ou a habilidade das pessoas para refletirem sobre a abertura a novos elementos sociais e simbólicos da composição dos teko pyahu - modos de ser e conhecer contemporâneos próprios dos Kaiowa -, que compóem a multiplicidade de seus estilos comportamentais atuais - teko laja reta.

As fofocas (ñé vai) e os comentários jocosos afetam aspectos morais da pessoa e de sua família, porque dizem respeito ao laja, que se refere a meios de identificaçáo da conduta e estilos familiares expressos pela pessoa, como, por exemplo, ser convertido a uma igreja neopentecostal exige da pessoa uma conduta que articule "ser índio e ser crente". ${ }^{13}$ Tais questóes também estão presentes nas reflexóes e na mediação entre valores considerados tradicionais, pois as fofocas e jocosidade produzem efeitos nas percepçóes geracionais. Para os interlocutores, quando os questionei a respeito de como pensam sobre si, a partir da visão dos homens kaiowa mais velhos (tudja), comentaram comigo que, na visão dos [Kaiowa e Guarani] tradicionais, nem indio a gente é.

Essa sentença, dita por um dos jovens, condensa uma ampla compreensão dos modos como as transformaçóes são pensadas a partir das categorias que expressam leituras sobre o modo de ser atual entre os Kaiowa (teko pyahu) e atua como um mediador das relaçóes entre o ñande reko - nosso 
modo de ser kaiowa e guarani - e o karai reko - modo de ser dos brancos, no qual tradicionais é uma categoria nativa utilizada para descrever parentelas e pessoas vinculadas ao xamanismo e à luta política pela demarcação de terras kaiowa e guarani no Mato Grosso do Sul.

De certo modo, a condição de jovens e sem filhos, atuando em atividades identificadas como de branco e morando fora da aldeia, os coloca em posições de alteridade que sugerem um distanciamento ambíguo do modo de ser kaiowa, ou, mantendo uma boa distância precária. E, à medida que buscam estratégias para evitarem ser identificados como homossexuais, incorrem no risco de se afastarem excessivamente do modo de ser kaiowa e guarani - ñande reko -, pois, para não evidenciar sua sexualidade, eles próprios assumem que náo podem pôr à prova os discursos dos mais velhos sobre a tradição. Desse modo, a conduta individual sempre será alvo de comentários, visto que esses jovens não se tornam "adultos completos", chegam à maturidade sem ter filhos e, com isso, diminuem as possibilidades de prestígio familiar na aldeia.

Por outro ponto de vista, ao ocuparem postos de trabalho nos serviços públicos (que são também políticos) na aldeia, passam a incorporar outras formas de prestígio, devido ao domínio de saberes dos brancos, obtidos a partir da escolarização. Desse modo, a capacidade de inovar, transformando a potência dos conhecimentos dos brancos, lhes é conferida a partir do modo como estendem e transformam os sentidos (inter e intra) geracionais dos conceitos de tradição e inovação (CARIAGA, 2015). A homossexualidade não assumida por eles insere "algo novo", mas não figura como um dos comportamentos diretamente identificados como "modernos" 14 pelos Kaiowa, ainda que se trate de um silenciamento que perturba.

O comentário expresso pelos mais velhos, que, na opinião dos interlocutores, são os conhecedores por excelência do modo do ser dos antigos (teko ymaguare), ao identificar o conjunto das condutas dos homens mais jovens (kuimba'e kuera) como moderno (laja pyahu), produz distanciamentos do modo correto de se viver (teko porã). Mas os interlocutores são enfáticos em apontar que partilham os mesmo valores, mas que compreendem de modos diferentes o ñande reko, porque as perspectivas são formuladas de modo distinto por quem as enuncia. Assim, as categorias que relacionam ser e conhecer entre os Kaiowa são sempre pontos de vista de uma geração sobre a outra. Pois os jovens vivem experiências particulares à sua geração com o modo de ser dos brancos (karai reko), assim como os velhos vivenciaram em sua juventude, e expressam reflexóes, nesse caso, sobre como pensam as diferenças entre os gêneros e as geraçóes ao longo do tempo.

Desse modo, a multiplicidade de estilos de conduta (ava laja kuera) é constitutiva do ñande reko - categoria traduzida pelos Kaiowa de modo ha- 
bitual como "nosso modo de ser", no singular, mas que pode ser entendida no plural, como nossos modos de ser, já que se refere ao ñande (nosso) como categoria que agrega amplas formas de relação. ${ }^{15}$ Todavia, isso não significa que essas ontologias estejam em disputa nas reflexôes contemporâneas dos Kaiowa. A homossexualidade náo parece ocupar uma posiçáo central nas reflexôes a respeito da transformação. Entretanto, os estilos de conduta que refletem sobre a inovaçáo carecem de leituras que partam do acordo com as moralidades nativas.

Os comportamentos, moralidades ou estilos descritos como modernos (teko pyahu) oscilam entre arandu ymaguare (conhecimento dos antigos) e arandu ko'anga (conhecimentos de agora), ou seja, são conceitos que se movimentam a partir das relaçóes que produzem entre si. A homossexualidade dos jovens interlocutores kaiowa é vista como um problema, quando mobiliza a atenção dos mais velhos, no que tange às transformaçóes e inovaçóes nas formas idealizadas da socialidade, como a noção de teko porâ - modo bom e correto de ser e viver para os Kaiowa, ensinado no tempo demiúrgico. Todavia, estes termos podem ser lidos enquanto marcadores temporais, como ymaguare (antigo, passado), koa'nga (presente, atual), pyahu (novo, moderno), mas, quando compostos com teko, acionam potentes formas de explicação e significação do mundo.

Teko ymaguare expressa um conjunto de práticas, habilidades, moralidades, conhecimentos e reflexividade sobre os conhecimentos dos antigos ou como os antigos (mais velhos humanos e não humanos) descrevem o mundo. Teko pyahu, por sua vez, aponta para a possibilidade de pensar a inovação a partir do teko. A inovação não se refere à noção de futuro como algo impreciso, mas como um vir a ser, ou seja, o modo de ser atual (teko koa'nga) é um tempo/modo de testar formas de ser que possam vir a ser, no futuro, um modo de ser kaiowa - laja pyahu. Os conceitos estão relacionados um ao outro, pondo em rede diferentes agências e modos de pensar a pessoa, pois colocam o modo de ser (ñande reko) no campo das relaçóes, não o restringindo a uma noção de valor. Desse modo, a pessoa kaiowa é entendida como um campo de relaçóes que conecta modos de ser que articulam diferentes moralidades.

A suposição dos jovens interlocutores de que a homossexualidade é uma conduta emergente, resultante da intensificação da relação com os brancos, pode ser posta em contestação a partir de trabalhos como o de Chamorro (2009), sobre termos e léxicos registrados pelo Pe. Antônio Ruiz de Montoya, em que há claras referências à práticas homossexuais masculinas. A autora realiza uma investigação a partir das obras El vocabulario e El tesoro, nas quais Montoya registra termos como ava kunã eko, que é traduzido como "afeminado", e expressóes como che atukupe rupi che moangaipa - 
“pecou comigo por trás”. Em suas consideraçóes, a autora sugere que a imposição de monogamia e a total reprovação das práticas homossexuais são condutas e traduçóes missionárias que, ancoradas na perspectiva moral cristá, produziram efeitos marcantes na socialidade dos coletivos guarani e tiveram seus efeitos potencializados com a experiência da conversáo evangélica e neopentecostal a partir da metade do século XX. ${ }^{16}$

A condição de liminaridade dos jovens kaiowa é acentuada quando estes têm condutas entendidas como ruins ou perigosas - laja vai. Não que a homossexualidade esteja imediatamente elencada nas formas de ação potencialmente desagregadoras da pessoa kaiowa e guarani, mas ela produz uma imagem de insuficiência devido à condição de não ter filhos e não viver na aldeia, entre seus parentes. A cosmologia e a produçáo da pessoa entre os Kaiowa e Guarani são marcadas pela instabilidade da própria condição de humano.

Mesmo anteriormente ao nascimento, a produção da pessoa kaiowa é marcada pela mediação entre os humanos e os seres celestes, pois o nascimento de uma criança agencia potências e afecçóes que compóem o teko mbarete, que os Kaiowa traduzem como conjunto de ensinamentos, conhecimentos e técnicas para produção de corpos saudáveis (CARIAGA, 2012). Sobre essa relaçáo existe um amplo e rico material etnográfico das descriçóes do ñée - porçáo celeste da alma que vem tomar assento e deve ser seduzida para permanecer no patamar dos humanos. ${ }^{17}$ Porém, ainda é pouco explorado o rendimento sobre o uso de remédios do mato (pohá ka'aguy) e de rezas (ñembo'e) na produção e diferenciaçáo dos corpos saudáveis de mulheres e homens, como demonstrou Seraguza (2013).

Ao falar desse assunto com uma ñandesy - xamá mulher kaiowa que tem grande reputaçáo como especialista em saber potencializar o uso de ñembo'e com os remédios do mato (pohã ka'aguy), para que outras mulheres que pretendem se casar consigam engravidar e ter filhos -, ela descreveu-me que, durante a gestação, a combinação adequada entre ñembo'e e pohã kảaguy poderia influir na definição do sexo da criança. Essa técnica, segundo ela, era perigosa porque, quando Nande Ramói - ser criador dos Kaiowa - foi criando os mundos e os cosmos kaiowa, ele dividiu os conhecimentos entre diversos donos e patamares, assim como saberes próprios aos homens e outros exclusivos às mulheres. Ao criar as plantas e as matas, definiu que algumas espécies seriam de uso particular para os conhecimentos dos homens (kuimba'e arandu), e outras, para os saberes das mulheres (kunã arandu).

As plantas que possuem eficácia sobre o corpo da mulher são aquelas que nascem nos lugares mais úmidos e amenos, como próximo a rios, la- 
gos e no brejo, e têm o poder de abrandar as substâncias femininas, como o sangue e o leite materno. A ñandesy explicou que era possível, com uso das plantas certas, influir na definição do sexo da criança, contudo, era muito perigoso e arriscado porque o cheiro do corpo da mulher grávida atrai muitos seres não humanos, que tomam formas humanas e são capazes de interferir na gestaçáo, transformando a criança em algo não desejável. Grande parte da narrativa da ñandesy centrou-se em definir quais eram as regras e restriçóes que deviam ser seguidas pelo casal, tanto alimentares quanto sexuais, laborais e xamânicas, mas qualquer desvio na conduta do casal poderia resultar no nascimento de uma criança com alguma deficiência ou puto, termo regional muito utilizado como gíria para gay.

Quando abordei, no diálogo com meus interlocutores, a narrativa e o conteúdo da conversa, a reaçáo imediata foi o argumento de que os antigos sabiam de muitas coisas, mas do tempo deles, que nos dias atuais não era possível, já que as coisas tinham mudado muito. Na avaliação deles, era possível que a negação ou a resistência à homossexualidade entre os Kaiowa e Guarani mudasse, pois sabiam de outros homossexuais e até mesmo arranjos conjugais entre casais em que os homens mantinham relaçóes sexuais, porém eram casados com mulheres e tinham filhos, mas optaram por morar numa área contigua à aldeia, para não sofrerem retaliaçôes das lideranças religiosas e políticas. Nesse sentido, estar fora das relações cotidianas da aldeia produz um bom distanciamento, que garante uma menor intromissão na vida das pessoas, contudo, afastar-se demais das formas de convivialidade pode conduzir a uma aproximação perigosa da pessoa kaiowa ao modo de ser dos brancos - ava jopara.

$\mathrm{O}$ que a homossexualidade debatida com os jovens parece evidenciar são modos em que a produção das diferenças geracionais e de gênero emergem nas relaçóes entre os Kaiowa. Entretanto, alguns aspectos são mais destacados, como ter uma idade que os classifica como adultos e náo ter filhos, o que os impede de assumirem posiçóes de chefia e prestígio, pois isso desafia a centralidade do casamento para a produção da socialidade kaiowa. Contudo, parte das pressóes é aliviada pela capacidade de provimento econômico, devido aos salários dos postos de trabalho que ocupam. Como ouvi de um dos jovens, "para ser homem eu não presto, mas para pagar as contas eu valho alguma coisa".

As transformaçóes produzidas pelo trabalho assalariado são um ponto de partida interessante para a compreensão das relações entre homens e mulheres na condução familiar, visto que esse processo avolumou-se devido à densidade demográfica e à precarização dos recursos naturais para produção de roças, caça e pesca no interior da aldeia de Dourados. Com a expansão das monoculturas, o trabalho remunerado fora da aldeia, a apo- 
sentadoria dos idosos e o incremento dos programas de transferência de renda constituem as principais formas de manutenção econômica das famílias.

Esse cenário tem produzido efeitos no que diz respeito à posição e ao prestígio das mulheres kaiowa e guarani frente à participação política em espaços que antes eram ocupados pelos homens. Neste momento não poderei desenvolver reflexóes que dialoguem com pesquisas que já abordam a produção das relaçóes e de conceituaçáo sobre gênero entre os coletivos falantes de guarani, como, por exemplo, as pesquisas de Pereira (2015, 2008, 2004a) e Pissolato (2012, 2007). Estas, assim como textos publicados posteriormente pelos autores citados, compóem um bom panorama sobre o desenvolvimento dessas análises, que enfocam a questão do prestígio da complementariedade do casal na organização social, parentesco, cosmologia e liderança. Neste momento, procuro somente pôr em reflexão breves trechos dos discursos dos meus interlocutores sobre transformaçóes na agência e no papel público das mulheres kaiowa e guarani e como tal movimento também pode incorporar a aceitação da homossexualidade.

Olha, eu acho que um dia pode mudar, não sei se vai ser que nem tá sendo para vocês, né? Que agora pode casar, as pessoas aceitam mais. Mas se você ver [sic.], com os indígenas também mudou, no caso das mulheres, né? Antigamente você não via tanto direito ou elas correndo atrás deles. Ficava tudo em casa e os maridos quando voltavam do trabalho gastavam o dinheiro bebendo nos botecos do caminho da aldeia. De um tempo para cá mudou, eu vejo a diferença entre minha avó e minha mãe, com as minhas irmãs e primas da minha idade. $O$ fato de ter salário faz com que aceite mais as posiçóes delas, porque agora é igual no sustento da casa. Para você ver, eu nunca poderia ter uma casa com outro homem, mas eu que mantenho a casa da minha vó e da minha mãe lá na aldeia.

As transformaçóes nas posiçôes das mulheres kaiowa e guarani, no que tange a questôes políticas e econômicas na vida das famílias, emergem como fundo para comentários sobre a percepçáo dos processos contemporâneos que produzem efeitos nas relaçóes entre os gêneros. Do ponto de vista das formas de organizaçáo e gestão das famílias kaiowa, o prestígio político do chefe é também da chefe, vide a importância da conjugalidade expressa nos pronomes masculinos e femininos e na noção de jekoha - esteio ou suporte da família, encabeçado por um casal de prestígio, hỉu e hia .

Contudo, o assalariamento e prioridade às mulheres nos programas de transferência de renda têm definido novos aspectos na produção da sociali- 
dade, pois demonstram que ser mulher indigena mudou, como refletiu um dos jovens entrevistados, que durante a conversa elencou muitos comportamentos, condutas e valores que antes não eram atribuídos como modo correto de ser das mulheres - kuna 'kuera lajaporã. Situaçôes como se observa nos dias atuais, em que as mulheres demoram mais para casar devido ao interesse pela escolarização e profissionalização, assim como o aumento de mulheres que chefiam famílias ao se separarem, antes visto como comportamentos de mulheres extremamente sexualizadas - china haku -, atualmente são vistas como importantes, porque os tempos mudaram e exigem dos homens e das mulheres ajustes na socialidade para continuarem produzindo o ñande reko.

Nesse sentido, a partir de nossas conversas, pude constatar que as aspirações de meus interlocutores refletiam sua expectativa de que a sua homossexualidade também fosse compreendida como uma dessas coisas que podem mudar com tempo. Não percebi críticas ou tentativas de dissolução das distinções dos papéis atribuídos aos gêneros na vida social kaiowa. Mas, através das transformaçóes nos modos de ser das mulheres, eles podiam vislumbrar a possibilidade de um dia poderem se assumir entre seus parentes, pois a mediação entre categorias, conceitos e princípios que aludem à "tradição" (teko ymaguare) e à "inovação" (teko pyahu) são processos em que a agência e os conhecimentos da geraçáo à qual pertencem podem criar condiçóes para que homossexualidade vivenciada por eles talvez possa atuar como mais um elemento para a multiplicidade de formas de ser kaiowa - laja kuera.

\section{Algumas considerações}

A aproximação dos estudos sobre sexualidade e homossexualidade com a etnologia indígena ainda caminha de forma tímida. Tal razão não é tributária à inexistência de cenários etnográficos nos quais tais relaçóes existam ou em detrimento das dimensóes mais públicas da vida social. Avalio que as pesquisas ainda se debatem por conta da dificuldade de comparação entre os modos como a vida sexual entre os indígenas é vivida, centrando-se excessivamente nos modos não indígenas de pensar o corpo, o prazer, a reprodução, o parentesco e a política. Pois, como demonstrou Lévi-Strauss, especialmente na tetralogia e nas pequenas Mitológicas, a mitologia ameríndia nas terras baixas é povoada por uniōes, separações, filhos, famílias compostas por entes de diversas naturezas, em que as relaçóes produzidas entre eles são potentes meios de descrever as formas das transformaçóes na socialidade.

No texto náo pude explorar os desdobramentos dessa possibilidade devido à própria forma como foram conduzidas as entrevistas, cujo interesse 
era bem delimitado. Entretanto, ao refletir sobre o material levantado e acompanhar o cotidiano na Reserva Indígena de Dourados, destaco a importância de trazer para a análise da vida social ameríndia, nesse contexto, contribuiçóes a partir de interesses relacionados ao gênero, sexualidades, geração e moralidades, como uma maneira também de ampliar as formas de análise da etnologia indígena.

Avalio que, ao realizarmos um movimento de aproximação de chaves analíticas pouco utilizadas nas "pesquisas clássicas de etnologia indígena", como corpo, pessoa e parentesco, podemos ir de encontro aos apontamentos de Carsten (2000). Para a autora, esses termos estão localizados na história da antropologia, centrados em questóes como organizaçáo social, regras e sistemas de atitudes, relegando ao segundo plano as relaçóes. Todavia, sua teoria das relaçóes - relatedness (CARSTEN, 2000, p. 1-20) - se preocupa em retomar pesquisas nesse campo tendo como perspectiva o modo como emergem novos modos de relacionalidade nos contextos de pesquisas etnológicas, atento a como os interlocutores atribuem sentindo a um amplo campo de relaçóes que convencionamos chamar de parentesco, e, por que não, também trazer tais questionamentos para pensarmos a produção da pessoa entre os ameríndios nas terras baixas?

No caso dos coletivos guarani, a ação missionária iniciada em conjunto com o processo de contingenciamento territorial entre os Kaiowa e Guarani no Mato Grosso do Sul, no início do século XX, acentuada com a presença do neopentecostalismo e a conversão dos índios, a partir dos anos 1980, produziram ao longo da história do contato a imposição da moralidade cristã e também da monogamia e da heteronormatividade. Os efeitos desse longo processo podem ser lidos a partir do que Foucault (2008) denominava de biopoderes, em que a ação das tecnologias e formas de poder modernas (o autor refere-se ao Estado, mas neste caso incluo também as instituiçóes religiosas), como formas de governo sobre a vida das pessoas.

Nesse sentido, a moralidade ameríndia, conforme proposta por Sztutman (2009) e Teixeira-Pinto (2009) é confrontada por outras formas de moralidade, em que o mito e o rito não estáo no centro das descriçôes para a produção das formas de relação. Desse modo, a homossexualidade que os jovens kaiowa vivem pode ser lida como comportamento ou moralidade modernos - teko pyahu - desde que possibilitem conexóes e desconexóes com o que significa estar relacionado.

Assim, as narrativas presentes nas conversas com os jovens kaiowa me levam a pensar que o gênero e a sexualidade indígena não são como binarismos que se fecham em ser homem e não ser homem, nem mesmo que os termos como gays, lésbicas, travestis e transgêneros nos asseguram uma aproximação da maneira como vivenciam seu modo de ser, pois não são 
dimensôes de simples tradução. Podemos, no entanto, refletir a partir do que sugere Butler (2010) ao se referir a como as pessoas criam novas ordens de produçáo do corpo, do sexo e do gênero. No caso dos interlocutores, saber não só como performam o gênero, mas como "combinam performativamente" ser índio e ser gay ou ser gay e ser índio.

\section{Notas}

1. Este artigo deriva de um paper apresentado no seminário Foucault na Amazônia? Sexualidades Indígenas, organizado pelo NAnSI/PPGAS-MN/UFRJ, NAIPE/PPGSA-IFCH/UFRJ e CEsTA/USP, em 2015, no Rio de Janeiro. Agradeço aos comentários das organizadoras do evento, Luisa Elvira Belaunde, Elsje Lagrou e Marina Vanzolini. Agradeço, do mesmo modo, pelos comentários dos e das participantes, em especial a Patrícia Carvalho, Paulo Tássio, Juliana Rosalen, Diego Madi. Agradeço também a leitura prévia de Marcelo Camargo e Lauriene Seraguza.

2. Em 2010, Ângela Sacchi e Marcia Gramkow organizaram, na $27^{\mathrm{a}} \mathrm{RBA}$ e no 9o Fazendo Gênero, o grupo de trabalho "A centralidade do gênero em povos indígenas", e em ambas as atividades náo houve trabalhos que abordassem a temática.

3. Iniciei minha pesquisa de campo no final de 2010 e defendi a dissertação em agosto de 2012, todavia, em 2011 passei a atuar como assistente técnico da Coordenação Regional da Fundação Nacional do Índio, em Dourados, onde permaneci até 2014.

4. Durante a pesquisa de campo, uma "equivocação" garantiu que eu pudesse dar continuidade à pesquisa, realizada entre 2010 e 2012. Nesse período, passei a dividir a residência com uma amiga que fazia mestrado em antropologia, devido à nossa proximidade e afetividade, para muitos interlocutores éramos um casal, condição que me assegurava um prestígio e possibilidade de ter filhos. $\mathrm{Na}$ época náo percebi o efeito que isso teve na condução da pesquisa, o que ficou claro somente quando um interlocutor me questionou por que havia me separado da minha esposa. Não entendi a quem ele se referia, pois nunca havia me casado, mas também não dissipei o desentendimento para compreender o raciocínio dele e, na sequência dos entendimentos equivocados, ele salientou que eu era novo e poderia me casar novamente e assim ter filhos.

5. Em sua pesquisa de mestrado, em andamento no PPGE/UCDB, Claudemiro Lescano (2014, p. 07, grifo do autor), pesquisador kaiowa, identifica vários princípios e condutas que relacionam o teko (comumente descrito como cultura e/ou conhecimento) a uma "moralidade kaiowa", ou, nos termos do autor, "linhas culturais são inúmeros outros elementos intro- 
jetados na estrutura dessa linha como seguimentos e ordens para manifestação contínua de identidade própria. Essa teia de valores culturais são subsídios adentrados nessas estruturas como ferramentas de processo de ensino-aprendizagem tradicional tendo as palavras como interruptoras ou princípio para viver o chamado teko".

6. Em sua descrição da organização e do parentesco kaiowa, Pereira (1999, 2004), chama atenção para a importância da noção de fogo familiar. A categoria proposta pelo autor (PEREIRA, 2002) diz respeito à conceituação kaiowa da noção de família, que extrapola os limites da consanguinidade e da descendência. Fogo familiar é a tradução para che ypykuera - que pode ser entendido como "aqueles que se originam de mim" - categoria do parentesco fortemente marcada pela comensalidade, em que pertencimento a um fogo familiar é condição fundamental na produção da pessoa.

7. A junção do pronome ñande (nós) com o substantivo reko (jeito, modo, estilo) enuncia o modo como os diferentes coletivos falantes de língua guarani dão sentido a uma ampla forma de conceituação do modo de ser entre os Guarani.

8. Ore é também o pronome "nós", entretanto, os Kaiowa utilizam-no para marcar e estabelecer as diferenças entre eles e outros coletivos guarani. Quando usam ore kuera, excluem os interlocutores que não são identificados como parentes e/ou aliados. Com frequência traduzem ore reko como "nosso sistema", que é um modo de expressar o ponto de vista kaiowa, criando multiplicidades de modos de ser e conhecer até mesmo entre os próprios Kaiowa. Nesse sentido, Benites (2009) aponta que a composição das relações familiares entre os Kaiowa, o que familiariza e coletiviza as pessoas, mais do que os laços de consanguinidade e de descendência seria o "estilo de conduta de cada família kaiowa - teko laja" (BENITES, 2009, p. 19). Nesse sentido, ore reko é uma composiçáo contextual e histórica do laja, e atua como um marcador e mediador das transformaçóes, pois, diante da intensificação das relaçôes com o modo de ser dos brancos (karai reko) e com outros falantes de guarani, as famílias kaiowa passaram a incorporar novos modos de ser e conhecer (teko pyahu) à produção dos seus laja. Assim, estendem e inovam os modos de ser e conhecer kaiowa - ore rekote'e.

9. Seraguza (2013, p. 35), em sua etnografia dos Kaiowa e Guarani, interessada em descrever a corporalidade e a cosmologia a partir das mulheres, estabelece a seguinte compreensão "pajevaí, o feitiço que mata, adoece, faz o feio e a ruptura, e o pajéporá, o belo, que aproxima, que reproduz e potencializa os sentimentos".

10. A Reserva Indígena de Dourados (RID) é uma área criada, no início do século XX, pelo Serviço de Proteção aos Índios, com cerca de 3.500 hectares, para recolhimento das parentelas kaiowa e guarani que viviam na regiáo, 
com vistas à liberação do território para colonização. Atualmente vivem no interior da RID cerca de 15 mil pessoas, em condiçóes totalmente adversas às descriçôes sobre o modo de ser e viver kaiowa e guarani (teko porā), o que produz efeitos sobre a socialidade e as formas de produção da vida social. $\mathrm{Na}$ área também moram famílias Terena, com quem produziram relaçóes de matrimônio e alianças políticas no decorrer de quase um século de vida nas reservas.

11. Quando foi criada, em 1917, a RID ficava a cerca de treze quilômetros do núcleo urbano, porém, a expansão demográfica e urbana fez com que os limites de crescimento da zona urbana tangenciassem a reserva indígena. Atualmente o limite geográfico entre cidade e aldeia é quase inexistente, devido à construçáo de um anel viário que contorna as aldeias e uma rodovia estadual que passa ao meio. Contudo, política e simbolicamente esses limites são dados de outras formas, como a hostilidade e o preconceito regional, alimentados pelo agronegócio, devido aos impasses na demarcação de terras kaiowa e guarani-tekoha, na região.

12. Atualmente me encontro na pesquisa de campo na regiáo de Dourados, mas me concentrando nas duas aldeias, Bororó e Jaguapirú, que compóem a Reserva Indígena de Dourados. $\mathrm{O}$ interesse da pesquisa é descrever etnograficamente os efeitos da intensificação das relaçóes do modo de ser kaiowa com o modo de ser dos brancos, a partir do aumento da presença do dinheiro no cotidiano.

13. Pereira (2004b) demonstra que a conversão dos Kaiowa às religiōes neopentecostais, a partir dos anos 1980, pode ser compreendida como uma das formas das transformaçóes no que tange à atenção às descrições dos modos como o coletivo produziu novas formas e estilos de condutas familiares teko laja pyahu - a partir da criação de "igrejas indígenas", dirigidas por chefes familiares, como estratégia política de produção de diferença entre as parentelas em ambientes como as reservas indígenas. Outras referências etnográficas ao processo de conversão religiosa entre os ameríndios estão nas coletâneas organizados por Wright (1999, 2004), Vilaça \& Wright (2009) e Wiik (2010).

14. O uso de "moderno" aqui se refere às traduçôes kaiowa sobre o modo de ser atual (teko pyahu), categoria que articula noçôes acerca da temporalidade e moralidade kaiowa e que não atua somente como um marcador temporal, mas como um conceito que situa na pessoa a capacidade de mobilizar discursos sobre a tradição e inovaçáo a partir do modo de ser kaiowa - ore reko. $\mathrm{Na}$ pesquisa realizada para o mestrado (CARIAGA, 2012), procurei descrever alguns comportamentos e papéis políticos identificados pelos Kaiowa de Te' ýikue como "modernos ou atuais - teko koa’nga". 
15. Lescano (2014), em sua pesquisa, procura compor um quadro de descriçôes sobre o teko que atualiza o esquema conceitual proposto por Melià, Grünberg \& Grünberg (2008, p. 103): “teko porã és ló que esta bién [...] por un cuadro de virtudes antes todo sociales, pero rigen comportamentos individuales".

16. Com relação aos efeitos da cristianização missionária e evangélica entre os coletivos guarani no Brasil, textos como os de Brand e Vietta (2004), Pereira (2004a) e Fausto (2005) fornecem um panorama etnológico e histórico sobre as transformações que estes eles implicam.

17. Sobre os Kaiowa e Guarani no Mato Grosso do Sul, sugiro a leitura de Schaden (1974 [1954]), Melià, Grünberg \& Grünberg (2008, 2.ed.), Chamorro (2008, 1999), Montardo (2009).

\section{Referências bibliográficas}

ARISI, Barbara M. Vida sexual dos selvagens (nós): indígenas pesquisam a sexualidade dos brancos e da antropóloga. In: SACCHI, A.; GRAMKOW, M. Gênero em povos indígenas. Rio de Janeiro/Brasília: Museu do Índio/GIZ/ FUNAI, 2012. p. 50-77.

BRAND, Antônio J.; VIETTA, Katya. Missões evangélicas e igrejas neopentecostais entre os Kaiowa e os Guarani em Mato Grosso do Sul. In: WRIGHT, R. M. (Org.). Transformando os deuses - v. II. Campinas: Editora da Unicamp, 2004. p.219-301.

BUTLER, Judith. Problemas de gênero: feminismo e subversão da identidade. São Paulo: Civilização Brasileira, 2010.

CARIAGA, Diógenes E. "Para fazer nossa cultura aparecer": equivocaçóes e reflevixidade entre os modos de conhecer entre os Kaiowa e a educação escolar. Texto apresentado no "ST 07: Pretensóes disciplinares e desafios" na V Reunião de Antropologia da Ciência e da Tecnologia, Porto Alegre, 2015.

. As transformaçôes no modo de ser criança entre os Kaiowa em Te' yikue (1950 - 2010). , Dourados, 2012. Dissertação (Mestrado) - PPGH-História Indígena, UFGD.

CAVALHEIRO DE JESUS, Suzana. Pessoas na medida: processos de circulação de saberes sobre o Nhande Reko Guarani na região das Missões, Florianópolis, 2015, Tese (Doutorado) - PPGAS/UFSC.

CARSTEN, Janet. Introduction: culture of relatedness. In: Culture of relatedness: new approaches to the study of kinship. Cambrige University Press, 2000. p. 1-20.

CHAMORRO, Graciela. Decir el cuerpo. Historia y etnografia del cuerpo en los pueblos Guaraní. Asunción: Tiempo de Historia/FONDEC, 2009. 
. Terra Madura - Yvy Araguyje. Fundamento da palavra guarani. Dourados: EDUFGD, 2008.

. Kurusu Nengatu. Palabras que la historia no podria olvidar. Asunção/ São Leopoldo: CEADUC/IEPG-COMIM, 1995. Biblioteca Paraguaya de Antropologia (25).

FAUSTO, Carlos. Se Deus fosse um jaguar: canibalismo e cristianismo entre os Guarani (séculos XVI - XX). Mana: Estudos em Antropologia Social, Rio de Janeiro, Editora Contra Capa, p. 385-418. 2005.

FERNADES, Estevão R. Homossexualidade indígena no Brasil: desafios de uma pesquisa. Novos Debates - Fórum de Debates em Antropologia, v. 1, n. 2, p. 26-33, jul. 2014a.

Pensando de forma náo situada: dilemas no estudo das homossexualidades indígenas no Brasil. Élisée - Revista de Geografia da UEG, v. 3, n. 1, p. 157-166. $2014 \mathrm{~b}$.

. Ativismo homossexual indígena e decolonialidade: da teoria queer às críticas two-spirits. 370 Encontro Anual da Anpocs - SPG 16: Sexualidade e Gênero: Espaço, Corporalidade e Relações de Poder. Águas de Lindóia, 2013.

FOUCAULT, Michael. $O$ nascimento da biopolítica. Curso no Collège de France (1978-1979). São Paulo, Martins Fontes, 2008.

LATOUR, Bruno. Jamais fomos modernos. São Paulo, Editora 34, 1995.

LEA, Vanessa. Parentesco enquanto uma elaboração sócio-cultural da percepção do dimorfismo sexual humano. In: AMADO, R. Estudos em línguas e culturas Macro Jê. São Paulo: Paulistana, 2010.

- Gênero feminino Mebengokre (Kayapó): desvelando representaçôes desgastadas. Cadernos Pagu, n. 3, p. 85-115. 1994.

LESCANO, Claudemiro. Fundamentos da educação guarani e kaiowá - processos próprios de ensino e aprendizagem na Aldeia Taquaperi em Mato Grosso do Sul. Texto apresentado no "GT Infâncias e Crianças: Pesquisas em Antropologia da Criança” - II Seminário Infância - Criança Indígena, OEEI-UFSCar/PPGAS-UFSCar, 2014.

LÉVI-STRAUSS, Claude. Antropologia estrutural. São Paulo: Cosac Naify, 2008. . A origem dos modos à mesa (Mitológicas v. III). São Paulo, Cosac Naify, 2006.

. História de Lince. São Paulo, Companhia das Letras, 1993.

MCCALLUM, Cecília. Notas sobre as categorias "gênero" e "sexualidade" e os povos indígenas. Cadernos Pagu, n. 41, p. 53-61, 2013.

MELIÀ, Bartomeu; GRÜNBERG, Georg; GRÜNBERG, Friedl. Etnografia guarani del Paraguay contemporaneo: Los Pai Tavyterã. 2.ed. Asunção: CEPAG/UCA, 2008.

MONTARDO, Deise Lucy. Através do Mbaraka. Música, dança e xamanismo Guarani. São Paulo: Edusp, 2009. 
PEREIRA, Levi M. Levantadores de parentela Kaiowá e Guarani em MS: agency e atualização de saberes na produção da socialidade. In: HEUSI, N.; CAVALHEIRO, S.; MELLO, C. (Org.). Compreensóes contemporâneas sobre os Guarani. Florianópolis, EDUFSC, no prelo.

A socialidade na família kaiowa: relaçóes geracionais e de gênero no microscosmo da vida social. Temáticas (PPGAS/Unicamp), Campinas, p. 177202. 2008.

. O pentecostalismo Kaiowá: uma aproximação aos aspectos sociocosmológicos e históricos. In: WRIGHT, R. M. (Org). Transformando os deuses - v. II. Campinas: Editora da Unicamp, p. 267 - 302, $2004 a$.

. Imagens Kaiowa do sistema social e do entorno. São Paulo, 2004b. Tese (Doutorado) - PPGAS/USP.

. Organizaçâo social e Parentesco Kaiowa. Campinas, 1999. Dissertação (Mestrado) - PPGAS/Unicamp.

PISSOLATO. Gênero, casamento e trocas com brancos. In: SACCHI, A.; GRAMKOW, M. Gênero em povos indígenas. Rio de Janeiro/Brasília: Museu do Índio/GIZ/FUNAI, 2012. p. 98-115.

SCHADEN, Egon. Aspectos fundamentais da cultura guarani. São Paulo: EPU/ Edusp, 1974 [1954, 1.ed.].

SERAGUZA, Lauriene. Cosmos, corpos e mulheres kaiowa e guarani: de Aña à Kuña. Dourados, 2013. Dissertação (Mestrado) - PPGANT/UFGD.

SZTUTMAN, Renato. Ética e profética nas Mitológicas de Lévi-Strauss. Horizontes Antropológicos, ano 15, n. 31, p. 293-319. 2009.

TEIXEIRA-PINTO, Márnio. Lévi-Strauss, as luzes e os instrumentos das trevas: sobre a moralidade selvagem. Revista Ilha, v. 11, n. 2, p. 193-217. 2009.

VANZOLINI, Marina F. A flecha do ciúme: o parentesco e seu avesso segundo os Aweti do Alto Xingu. Rio de Janeiro: PPGAS/MN/UFRJ, 2010.

VILAÇA, Aparecida N.; WRIGHT, Robin M. (Org.). Native Christhian: modes and effects of christianity among indigenous peoples of the americas. Farham: Ashgate Publishing Ltd, 2009.

WIIK, Flávio Braune. "Somos indios crentes": dialéticas do contato, alteridade e mediação cultural entre os Xokleng (Jê) de Santa Catarina. Campo Grande: Editora UCDB, 2009. p. 11-51.

WRIGHT, Robin M. (Org.). Transformando os deuses - v. I. Campinas, Editora Unicamp, 1999.

. (Org.). Transformando os deuses - v. II. Campinas: Editora Unicamp, 2004. 
464 | Diógenes Cariaga

autor Diógenes Cariaga

Doutorando no PPGAS/UFSC, pesquisador vinculado ao NEPI/PPGAS/UFSC e ao Grupo de Pesquisa Etnologia e História Indígena - UFGD e LEPAC/UFSCar. A pesquisa conta com financiamento do INCT Brasil Plural e do CNPq.

Recebido em 17/12/2015 Aceito para publicaçáo em 25/01/2016 